\title{
THE DIFFERENTIAL CHARACTERS OF CHARACINOID AND ERYTHRINOID FISHES.
}

\author{
By Theodore Gill, LL. D.
}

IN MY list of Families and Subfamilies of Fishes (1893) I have admitted two families of Heterognaths, Characide (or Characinidx) and Erythrinidæ. As the limits and concepts of which they are the expressions are quite different from those hitherto current, it is a duty to no longer defer the reasons which have influenced me.

The two families in question have been admitted by other naturalists, but have only been differentiated by the development of an adipose fin in one (Characinids) and the absence of it in the other (Erythrinids). The mere presence or absence of a bag of adipose tissue is, howerer, of too little importance to justify distinetion as a family character, although in most cases it happens to be coordinate with other features, and hence available as a diagnostic mark. ${ }^{1}$ Nevertheless, in at least the entire subfamily Stevardiinæ it fails, for the small fishes in question appear to be more nearly related to Tetragonopterines than to Erythrinines. A character of more importance, apparently coordinate with other structural modifications, and which has been the cause of my accepting the two families, is to be found in the structure of the posterior part of the skull. The differences observable in due examination are expressible in the following diagnoses:

$$
\text { Family CHARAOINIDA. }
$$

(Primary Synonymy.)

<Dermoptères, Duméril, Zool. Analytique, p. 146, 1806.

<Salmonidi, Rafinesque, Indice d'Ittiolog. Siciliana, p. 32, 1810.

<Dermopteria, Rafinesque, Analyse de la Nature, p. 87, 815.

<Characini, MülLer, Archiv Naturgesch., 9. Jahrg., I, p. 323, 1843.

<haracins (Characide), Agassiz, Rep. Brit. Assn. Adv. Sei., 1844, p. 293.

${ }^{1}$ The development of an adipose fin may occasionally fail as a generic and even specific character, as anong the Nannostomi. "Nur bei einer einzigen dieser Arten fehlt..die Fettflosse vollständig; bei einer zweiten Art besitzen von vier Exemplaren drei eine Fettflosse, während sie dem vierten Individuum fehlt" (Steindach ner, Ich. Beit., V, p. 74, 1876).

Proceedings of the United States National Museum, Vol. XVIII, No. 1056. 
$\times$ Characins, Valenciennes, Hist. Nat. des Poissons, XXI, p. 159, 1848.

$<$ Characina, Vogt, Zool. Briefe, II, p. 150, 1851.

$\times$ Myletida, ADAMs, Man. Nat. Hist., p. 108, 1854.

$\times$ Characinida, Richardson, Encyel. Brit., 8th ed., XII, p. 245, 1856.

$\times$ Characinoidei, Bleeker, Ennm. Sp. Piscium Archipel. Indico, p. 31, 1859.

$<$ Characinida, Günther, Cat. Fish. Brit. Mus., V, p. 278, 1864.

$<$ Characinide, Cope, Proc. Am. Assn. Adv. Sci., 1871, p. 333 (1872).

$<$ Characinida, Grle, Arrang. Fam. Fishes, p. 16, 1872.

< Citharini, Fitzinger, Sitzungsber. K. Akad. Wiss. Wien, LXXVII, 1. Abth., p. 37, 1873.

$<$ Characinida, Schmanda, Zool., II, p. 377, 1878.

$<$ Characinida, Jordan and Gilbert, Syn. Fishes N. Amer., p. 254, 1882.

$=$ Characida, Gill, Mem. Nat. Acad. Sci., VI, p. 131, 1893.

\section{(Secondary Synonymy.)}

$<$ Salmones, Cuvier, Règne Animal [1 $1^{\mathrm{e}}$ éd.], II, p. 159, 1817; 2e éd., II, p. 301, 1829. $<$ Salmonides, Latreille, Fam. Nat. Règne Animal, p. 119, 1825.

$<$ Salmones, Agassiz, Sel. Gen. et Sp. Piscium q. coll. Spix, p. 56, 1829.

$<$ Salmonida, Bonaparte, Giorn. Accad. di Scienze, III, p. 95 (Saggio Distrib. Metod. Animal. Vertebr. a Sangue Freddo, p. 37), 1832.

$<$ Salmonida, Swainson, Nat. Hist. and Class. Fishes, etc., II, pp. 184, $283,1839$.

$<$ Salmonida, Bonaparte, Nuovi Annali delle Sci. Nat., II, p. 132, 1838; IV, p. 272, 1840.

$<$ Characiniden, SAGEmenL, Morph. Jahrb., X, p. 1, etc., 1885.

\section{(Synonyms of Characinina.)}

<Characini, Latreille, Fam. Nat. Règne Animal, p. 119 ("Tribu”).

$<$ Salmonini, Bonaparte, Giorn. Accad. di Scienze, LII, 95 (Saggio Distrib. Metod. Animal. Vertebr. a Sangue Freddo, p. 37), 1832.

< Salmonina, Swainson, Nat. Hist. and Class. Fishes, etc., II, pp. 185, 286, 1839.

< Hydrocyonini, Bonaparte, Nuovi Annali delle Sci. Nat., II, p. 132, 1838; IV, p. 273,1840 .

<Characinini, Bonaparte, Cat. Met. Pesci Eur.,p. 5, 1846; Conspectus Syst. Piscium, 1850 .

$<$ Leiogastriformes, Bleeker, Enum. Sp. Piscium Archipel. Indico, p. xxxii, 1859. $<$ Hydrocyonina, GüNther, Cat. Fish. Brit. Mus., V, pp. 280, 345, 1864.

$<$ Hydrocyonina, Gill, Mem. Nat. Acad. Sci., VI, p. 131, 1893.

Heterognaths with the skull above more or less invaded by reentering valleys from behind, and the supraoccipital having a horizontal extension and carinated by a procurrent crest.

\section{Family ERYTHRINID A.}

\section{(Primary Synonymy.)}

<Erythröides, Valenciennes, Hist. Nat. Poiss., XIX, p. 480, 1846.

<Erythrinida, Richardson, Ene. Brit., 8th ed., XII, p. 250, 1856.

<Erythrinoidei, Bleeker, Enum. Sp. Piscium Archipel. Indico, p. xxxi, 1859.

=Erythrinida, Gill, Annals Lyc. Nat. Hist. N. Y., VI, p. 410, 1858.

<Erythrinida, Cope, Proc. Am. Assoc. Adv. Sei. 1871, p. 333 (1872).

<Erythrini, Fitzinger, Sitzungsber. K. Akad. Wiss., Wien, LXVII, 1. Abth., p. $37,1873$.

=Erythrinida, Gill, Mem. Nat. Acad. Sci., VI, p. 131, 1893 
(Secondary Synonymy.)

< Siagonotes, Duméril, 1806.

$<$ Clupeida, Bonaparte, 1832-1840.

$<$ Characini, Müller et al.

$<$ Characinida, Günther et al.

(Synonyms of Erythrinine.)

<Erythrichthini, Bonaparte, Nuovi Annali Sci. Nat., II, p. 132, 1838; IV, p. 196, 1840.

<Cyprina, Swansson, Nat. Hist. and Class. Fishes, etc., II, pp. 184, 283, 1839.

$<$ Erythrichthini, Bonaparte, Trans. Linn. Soc., XVIII, p. 300, 1840-41.

<Erythrichthini, Bonaparte, Cat. Met. Pesci Eur., p. 5, 1846; Cons. Syst. Pise., 1850 .

<Erythrinina, Günther, Cat. Fish. Brit. Mus., V, pp. 278, 281, 1864.

<Erythriniformes, Blekker, Enum. Sp. Piscium Archipel. Indico, p. xxxi, 1859.

$=$ Erythrinince, GILL, Mem. Nat. Acad. Sci., VI, p. 131, 1893.

Heterognaths with the skull above more or less truncated behind, and the supraoccipital confined to the posterior surface and carinated by a rudimentary or obsolete vertical crest.

There is good reason to believe that the Characinidæ, as here still preserved, constitute a heterogeneous group, and may hereafter be subdivided into two or more families, but the material at hand is insufficient to confirm the suspicions entertained or to properly refer the species to their respective families. Great differences are observable in the relative development of the jaws, the composition of the lower jaw, the branchial apparatus, etc. ${ }^{1}$

\section{BIBLIOGRAPHY.}

The illustrations of the skeletal features of the representatives of the family being much scattered, a list of most of them is here appended. More valuable than all others and accompanied by philosophical views are those given in Sagemehl's Memoir.

GENERAL BIBLIOGRAPHY

Sagemehl (Dr. M.). Beiträge zur vergleichenden Anatomie der Fische. I-IV.

Morph. Jahrbuch, IX-XVII, viz:

I. Das Cranium von Amia calva. IX, pp. 177-228, pl. 10, 1884.

II. Einige Bemerkungen iiber die Gehirnhäute der Knochenfische. IX, pp. 457-474, pl. 23, 1884.

III. Das Cranium der Characiniden, nebst allgemeinen Bemerkungen iiber die mit einem Weber'schen Apparat versehenen Physostomenfamilien, X, pp. 1-119, pls. 1, 2, 1885.

IV. Das Cranium der Cyprinoiden. XVII, pp. 489-595, pls. 28, 29, 1891.

${ }^{1}$ According to Sagemehl (III, p. 105, pl. 1, fig. 14), Citharinus has the lower jaw composed of only two lateral elements, a greatly elongated articular bone and reduced dentary. These peculiarities are coordinated with other cranial characters and with modifications of the branchial apparatus. Citharinus seems therefore to be the type of a peculiar family (Citharinidx). Of course such a family is very different from that named Citharini of Fitzinger, which is the same as Characinidæ. It would also differ much from the subfamily Citharina of Thominot (Bull. Philomath. Soc., (7) VI, p. 250, 1882), which includes the Citharinine and most of the Curimatinæe, but not the typical genus Curimata or the edentulous forms. The genera included by Thominot are Saccodon, Heniodus, Parodon, Citharinus, Prochilodus and Canotropus. 


\section{BIBLIOGRAPHY OF SPECIES. \\ Subfamily FiRYTHRININAE.}

Erythrinus unitaniatus, SPIX. ${ }^{1}$

Erythrinus uniteniatus, Sagement, Morph. Jahrb., X, p. 26, pl. 1, figs. 1-12 (skull), 1885; Eigenmann, Proc. Cal. Acad. Sc1. (2), II, p. 105, pl. 1, fig. 2 (jaws), 1889.

Macrodon tareira, BLOCH.

Macrodon trahira, Steindachner, Denkschr. Akad. Wiss. Wien, XLII (Fisch Cauca, p. 14), pl.5, fig. 3 (articulation of dentary), 1879.

Macrodon malabaricus, Eigenmann, Proc. Cal. Acad. Sei. (2), II, p. 102, pl. 1, fig. 1 (jaws), 1889.

\section{Subfamily PYRRIIULININ AE. ${ }^{2}$}

Pyrrhulina guttuta (STEINDACHNER).

Pyrrhulina guttata, Eigenmann, Proc. Cal. Acad. Sci. (2), II, p. 108, pl. I, fig. 3 (jaws), 1889.

\section{Subfamily LFBBASININ AE.}

Lebiasina bimaculata (CUVIER and VALENCIENNES).

Lebiasina bimaculata, Eigenmann, Proc. Cal. Acad. Sci. (2), II, p. 113, pl. I, fig. 5 (jaws), 1889.

\section{Subfamily TFTRAGONOPTFIRI $A$.}

Tetragonopterus mexicanus, FiLIPPI.

Tetragonopterus mexicanıs, SteindaChNer, Sitzungsber. K. Akad. Wiss., Math. Nat. Cl., LX, 1. Abth., p. 300 (Ich. Not., IX), pl. 4, figs. 2-4 (Phar. bones), 1869-70.

\section{Subfamily SFRRASAI.MONIN AE.}

Serrasalmo -

Serrasalmo — , Rosenthal, Ichthyotom. Tafeln, pl. 6, 1816.

Pygocentrus piraya, LACÉPìnE.

a. Pygocentrus piraya, Hyrti, Denkschriften K. Akad. Wiss. Wien, Math. Nat. Cl., XXI, p. 7, pl. [1], fig 5 (br. skel.), 1863.

b. Serrasalmo piraya, Klein, Jahreshefte d. Vereins f. Vaterl. Naturk. in Wiirttemberg, 40. Jahrg. (1884), pp. 157, 226, pl. 2, figs. 12, 13; 42. Jahrg. (1886), p. 261, pl. 7, fig. 28 ; p. 291 , pl. 8 , fig. 53 (cr. bones).

Myleus.

Myletes - Gervais, Castelnan's Expéd. dans l'Amérique du Sud,

Anat., p. 97, pl 2 (skull), 1856.

Myleus oligacantius (MǗLER and Troschel).

Myletes olygacanthus, KLEIN, Jahresheite d. Vereins f. Vaterl. Naturk. in Wiirtiemberg, 40. Jahrg. (1884), pp. 159, 227, pl. 2, figs. 14, 15.

${ }^{1}$ The genus Erylhrinus (Gronovius, Seopoli) was based exclusively on a species without pterygoid teeth, and consequently the section so distinguished should retain the name instead of Hetererythrinus, while the subgenus (or genus) differentiated by the development of pterygoid teeth (typified by E. unitaniatus, Spix) may be called Hoplerythrinus.

It seems advisable also to direct attention to the Grundulus of Valenciennes, referred by that naturalist next to Hydrargyra (XVIII, pp. 216-220). It appears to me to be related to Pyrrhulina, if not a species of that genus, and therefore a Characinid. Valenciennes himself. (XVIII, p. 219) remarked that it cannot be denied that the number of branchiostegal rays and the bilobate air bladder agree with Characin characteristics. 
Subfamily HYDROCYONIN AE.

Hydrocyon forskatii, Cuvier.

Hydrocyon forskali, KLern, Jahreshefte d. Vereins f. Vaterl. Naturk. in Wiirttemberg, 35. Jahrg. (1879), p. 104, pl. 1, fig. 13 (mast.); 40. Jahrg. (1884), p. 156, pl. 2, figs. 10, 11; 41. Jahrg. (1885), pp. 195, 211, pl. 3, figs. 73, 74; 42. Jahrg. (1886), p. 261, pl. 7, fig. 27; p. 291, pl. 8, fig. 52 (cr. bones).

\section{Subfamily MYIFTINAE.}

Myletes dentex, Linnaus.

Alestes dentex, Sagemenl, Morph. Jahrb., X, p. 26, pl. 2, figs. 17, 18 (skull), 1885.

Subfamily DISTICHODONTIN AE.

Distichodus agyptius, GMelin.

a. Distichodus niloticus, Hyrtu, Denkschriften K. Akad. Wiss. Wien, Math. Nat. Cl., XXI, p. 7, pl. [1], fig. 6 (br. skel.), 1863.

b. Distichodus kammar, Mettenhenier, Disq. anat. comp. membro pisc. pect., pl. 2, fig. 12 (sh. girdle), 1847.

\section{Subfamily A NOSTOMINAE.}

Leporinus elongatus, STEINDACHNER.

Leporinus elongatus, SteindachNer, Denkschr. K. Akad. Wiss. Wien, Math. Nat. Kl., XXXIX (Fish. Mag., pp. 38, 39), pl. 10, figs. 3-5 (preop. and quadrate), 1878.

\section{Subfamily CURIMATIN AE.}

Prochilodus brama, VALENCIENNES.

Prochilodus brama, Hyrte, Denkschriften K. Akad. Wiss. Wien, Math. Nat. Cl., XXI, p. 7, pl. [1], fig. 3 (br. skel.), 1863.

\section{Subfamily CITHARININAE.}

Citharinus geoffroyi, CUVIER.

Citharinus geoffroi, Hyrte, Denkschriften K. Akad. Wiss. Wien, Math. Nat. Cl., XXI, p. 7, pl. [1], fig. 4 (br. skel.), 1863.-SAGEMEHL, Morph. Jahrb., X, p. 26, etc., pl. 1, fig. 14; pl. 2, figs. 1-11 (skull), 1885.

${ }^{1}$ Myletinæ (or better Mylitinæ), not Myletidini- $\mu \nu \lambda \iota \tau \eta s, ~ o v$, millstone or grinder.

Proc. N. M. $95-14$ 


\section{$2 \mathrm{BHL}$ Biodiversity Heritage Library}

Gill, Theodore. 1896. "The differential characters of characinoid and erythrinoid fishes." Proceedings of the United States National Museum 18(1056), 205-209. https://doi.org/10.5479/si.00963801.18-1056.205.

View This Item Online: https://www.biodiversitylibrary.org/item/32799

DOI: https://doi.org/10.5479/si.00963801.18-1056.205

Permalink: https://www.biodiversitylibrary.org/partpdf/5702

\section{Holding Institution}

Smithsonian Libraries

\section{Sponsored by}

Smithsonian

\section{Copyright \& Reuse}

Copyright Status: NOT_IN_COPYRIGHT

This document was created from content at the Biodiversity Heritage Library, the world's largest open access digital library for biodiversity literature and archives. Visit BHL at https://www.biodiversitylibrary.org. 